\title{
Changes in Osmolal Gap and Osmolality in Children with Chronic and End-Stage Renal Failure
}

\author{
Hasan Dursun $^{a} \quad$ Aytul Noyan $^{a} \quad$ Nurcan Cengiz ${ }^{b} \quad$ Gulen Attila $^{c}$ \\ Mithat Buyukcelik $^{a} \quad$ Mustafa Soran ${ }^{a}$ Gulsah Seydaoglud Aysun K. Bayazit ${ }^{\mathrm{a}}$ \\ Ali Anarat ${ }^{a}$ \\ Departments of a Pediatric Nephrology, 'Biochemistry and dBiostatistics, Çukurova University School of Medicine, \\ and ${ }^{b}$ Department of Pediatric Nephrology, Adana Teaching and Medical Research Center, Baskent University \\ School of Medicine, Adana, Turkey
}

\section{Key Words}

Osmolal gap $\cdot$ Osmolality $\cdot$ Chronic renal failure

The osmolality and osmolal gap (OG) of physiological fluids tend to be dominated by small molecules which are present in high concentrations [1]. The OG is an indication of unmeasured solute in the blood; it is defined as the difference between the measured serum osmolality and the calculated serum osmolality [2, 3]. An OG value greater than $10 \mathrm{mosm} / \mathrm{kg}$ is considered a critical value, and it is clinically important in two conditions: (a) assessment of serum water content, especially in hyponatremia accompanied by hyperlipemia or hyperproteinemia; (b) evaluation of exogenous low-molecular-weight substances, such as ethanol, methanol and acetone.

Levels of OG and serum osmolality are important in pediatric patients and particularly in patients with chronic renal failure (CRF). In CRF patients under dialysis therapy, especially during hemodialysis (HD), when blood urea levels drop suddenly and significantly, a 'dialysis dysequilibrium syndrome' may develop. Therefore, there is an increased risk for neurological complications (such as cerebral edema) in CRF patients under HD treatment $[4,5]$. In several previous studies, OG was found within the reference range in patients with renal failure [6]. However, the role of OG and serum osmolality in this condition was not established very well. The aim of this study is to determine the serum OG and osmolality in children with various stages of CRF and the effect of dialysis modalities on these parameters. We also investigated the possible relationship among the changes of OG and serum osmolality before and after HD in patients with CRF.

We studied 101 patients (52 boys and 49 girls), with known CRF. Thirty-six patients (age range 5-16 years) underwent HD (HD patients), 29 patients peritoneal dialysis (PD patients) whose age range was 2-14 years, and 25 of them were on continuous ambulatory PD while 4 were treated by continuous cycling PD; 36 nondialyzed (age range 2-16 years) CRF patients (ND patients) were also included. There was a statistically significant difference in age between the PD and HD groups ( $p=0.013)$. All HD patients were treated by bicarbonate dialysis 3 times weekly with $0.4-0.7 \mathrm{~m}^{2}$ substituted cellulosic membranes. PD was carried out 4-6 times daily in continuous ambulatory PD patients and for 8-10 h/night in continuous cycling PD patients with $1.36 \%$ peritoneal dialysis solutions (Dianeal 1.36\%, Baxter-Eczacibası Healthcare, Istanbul, Turkey). There was no medication by mannitol in any groups. Samples of blood were obtained before and

\section{KARGER}

Fax +4161306 1234 E-Mail karger@karger.ch www.karger.com
(C) 2007 S. Karger AG, Basel

$1660-2137 / 07 / 1052-0019 \$ 23.50 / 0$

Accessible online at:

www.karger.com/nep
Prof. Dr. Aytul Noyan

Çukurova University School of Medicine

Department of Pediatric Nephrology

TR-01330 Balcalı, Adana (Turkey)

Tel./Fax+90 32233869 35, E-Mail naytul@cu.edu.tr 
Table 1. Serum biochemical profile (mean \pm SD) and differences between groups in children with renal failure

\begin{tabular}{|c|c|c|c|c|c|}
\hline \multirow[t]{2}{*}{ Parameters } & \multirow{2}{*}{$\begin{array}{l}\text { ND group } \\
(\mathrm{n}=36)\end{array}$} & \multirow{2}{*}{$\begin{array}{l}\text { PD group } \\
(\mathrm{n}=29)\end{array}$} & \multicolumn{3}{|c|}{ HD group $(n=36)$} \\
\hline & & & before HD & after HD & $\begin{array}{l}\mathrm{p} \text { (between before } \\
\text { and after HD) }\end{array}$ \\
\hline Sodium, mEq/l & $138.6 \pm 7.0$ & $135.8 \pm 3.9$ & $135.2 \pm 4.3$ & $137.2 \pm 3.9$ & 0.04 \\
\hline Potassium, mEq/1 & $5.0 \pm 1.2$ & $4.8 \pm 0.9$ & $4.9 \pm 1.4$ & $3.9 \pm 1.4$ & 0.000 \\
\hline $\mathrm{BUN}, \mathrm{mg} / \mathrm{dl}$ & $71.7 \pm 38.9$ & $66.6 \pm 26.1$ & $73.6 \pm 26.4$ & $33.7 \pm 11.9$ & 0.000 \\
\hline Creatinine, $\mathrm{mg} / \mathrm{dl}$ & $6.4 \pm 5.3$ & $7.4 \pm 3.3$ & $8.3 \pm 3.2$ & $4.8 \pm 2.0$ & 0.000 \\
\hline Glucose, mg/dl & $90.5 \pm 13.0$ & $90.6 \pm 23.1$ & $88.7 \pm 28.0$ & $95.2 \pm 30.0$ & 0.2 \\
\hline Protein, g/dl & $6.2 \pm 1.2$ & $5.9 \pm 0.8$ & $5.6 \pm 1.2$ & $5.9 \pm 1.3$ & 0.02 \\
\hline Albumin, g/dl & $3.6 \pm 1.0$ & $3.3 \pm 0.6$ & $3.5 \pm 0.9$ & $3.8 \pm 0.9$ & 0.02 \\
\hline $\mathrm{Osm}_{\mathrm{m}}, \operatorname{mosm} / \mathrm{kg}$ & $329.3 \pm 31.6^{\mathrm{a}}$ & $314.1 \pm 15.2$ & $327.5 \pm 31.6^{\mathrm{a}}$ & $311.0 \pm 20.5$ & 0.002 \\
\hline $\mathrm{Osm}_{\mathrm{c}}, \mathrm{mosm} / \mathrm{kg}$ & $307.9 \pm 19.1$ & $300.4 \pm 9.1$ & $301.6 \pm 13.2$ & $295.0 \pm 11.1$ & 0.01 \\
\hline $\mathrm{OG}, \mathrm{mosm} / \mathrm{kg}$ & $21.4 \pm 20.7$ & $13.7 \pm 14.5$ & $25.7 \pm 26.2^{b}$ & $15.2 \pm 17.6$ & 0.01 \\
\hline
\end{tabular}

$\mathrm{BUN}=$ Blood urea nitrogen; $\mathrm{Osm}_{\mathrm{m}}=$ measured serum osmolality; $\mathrm{Osm}_{\mathrm{c}}=$ calculated serum osmolality. ${ }^{\mathrm{a}} \mathrm{p}<0.05$ between before-HD group and PD group, and also between ND and PD groups.

${ }^{\mathrm{b}} \mathrm{p}<0.05$ between before-HD group and PD group.

after $\mathrm{HD}$ from $\mathrm{HD}$ patients and at any time from $\mathrm{PD}$ and ND patients. With centrifugation $(3,000 \mathrm{rpm}, 5 \mathrm{~min}$, $4^{\circ} \mathrm{C}$ ) serum was removed from other components of blood and was stored at $-80^{\circ} \mathrm{C}$ until study.

Serum osmolality was measured by a Knauer Osmometer Automatic (D-14163, Berlin, Germany) and calculations were based on the following formula: osmolality = $\left(2 \times \mathrm{Na}^{+}\right)+\left(\right.$glucose/18) $+(\mathrm{BUN} / 2.8)$ [3]. Serum $\mathrm{Na}^{+}, \mathrm{K}^{+}$, $\mathrm{BUN}$, creatinine, glucose, protein and albumin were determined by standardized procedures. Residual renal function was determined with the calculated creatinine clearance by the Schwartz formula [7] in ND patients, and adequacy of the dialysis method was established by $\mathrm{Kt} / \mathrm{V}_{\text {urea }}$ in $\mathrm{HD}$ [8] and in PD patients [9].

One-sample t test, Student's t test and paired t test were used for normally distributed continuous variables. Since the data were not distributed normally, appropriate nonparametric tests were chosen (Mann-Whitney U test and Wilcoxon rank sum test). Bonferroni's correction was applied ( $\mathrm{p}<0.05 / \mathrm{n}$, where $\mathrm{n}=$ number of comparisons) when multiple comparisons were made. All results are expressed as means $\pm \mathrm{SD}$. A p value lower than 0.05 was considered as significant.

Serum biochemical parameters and differences between groups are shown in table 1 . The mean urea reduction ratio in the HD group was $58.32 \pm 14.26$. The mean OG was statistically significantly higher in patients before HD than after HD. The mean OG of PD was statistically significantly lower than in the patients before HD.
The mean measured osmolalities of PD and after-HD patients were statistically significantly lower than those of the patients before HD and the ND patients. We compared our results with some main reference studies about this subject $[3,10,11]$. However, the OG and measured osmolality levels of our study were not significantly different in the PD group (13.7 \pm 14.5 and $314.1 \pm$ $15.2 \mathrm{mosm} / \mathrm{kg})$ and in patients after HD (15.2 \pm 17.6 and $311.0 \pm 20.5 \mathrm{mosm} / \mathrm{kg}$ ) than the reference levels $(5.0 \pm$ 14.0 and $290.0 \pm 5.0 \mathrm{mosm} / \mathrm{kg} ; \mathrm{p}>0.05$ ), but they were found to be significantly higher in ND patients (21.4 \pm 20.7 and $329.3 \pm 31.6 \mathrm{mosm} / \mathrm{kg}$ ) and in patients before $\mathrm{HD}(25.7 \pm 26.2$ and $327.5 \pm 31.6 \mathrm{mosm} / \mathrm{kg})$ when compared with reference values $(\mathrm{p}<0.05)$.

Hypernatremia caused by reduced water content can increase osmolality but does not cause a rise in OG, since the measured and calculated osmolalities are both high [11]. As OG and osmolality significantly decrease after HD sessions, HD patients have an increased risk of dialysis dysequilibrium syndrome [12]. OG values were normal in PD patients and significantly increased in ND patients and before HD. In addition, measured osmolality was significantly higher in patients before HD than in PD patients. According to our values, there were some osmotically active particles in the blood that changed serum OG and osmolality in CRF patients. We think that these changes were mainly due to elevations in BUN, creatinine and $\mathrm{K}^{+}$concentrations and these particles are cleared more rapidly in $\mathrm{HD}$ than $\mathrm{PD}$. 
In conclusion, monitoring of the OG and serum osmolality plays an important role to determine the risk of neurological complications in patients with CRF. Because the change of serum sodium levels does not influence it, OG must be calculated in patients who carry the risk of dialysis dysequilibrium syndrome. The surprising outcome in our study was the higher levels of OG and measured osmolality in patients before HD, but normal levels in PD patients. Therefore, when we have to decide on the dialysis modality, we should consider these results. We conclude that for those with a risk of neurological complications, PD should be the preferred method because a stable serum OG and osmolality have been shown to be achieved.

\section{References}

1 Greenbaum LA: Electrolyte and acid-base disorders; in Behrman RE, Kliegman RM, Jenson HB (eds): Nelson Textbook of Pediatrics, ed 17. Philadelphia, Elsevier Science, 2004, pp 191-242.

$\checkmark 2$ Dorwart WV, Chalmers L: Comparison of methods for calculating serum osmolality from chemical concentrations, and the prognostic value of such calculations. Clin Chem 1975;21:190-194.

-3 Oster JR, Singer I: Hyponatremia, hyposmolality, and hypotonicity: tables and fables. Arch Intern Med 1999;159:333-336.

$\checkmark 4$ Loutocky A, Lachmanova J, Tomasek R, Horky K: Changes in serum osmolality during hemodialysis of patients with chronic renal insufficiency. Cas Lek Cesk 1977;116: 177-181.
5 Silver SM, Sterns RH, Halperin ML: Brain swelling after dialysis: old urea or new osmoles? Am J Kidney Dis 1996;28:1-13.

6 Sklar AH, Linas SL: The osmolal gap in renal failure. Ann Intern Med 1983;98:481-482.

7 Schwartz GJ, Brion LP, Spitzer A: The use of plasma creatinine concentration for estimating glomerular filtration rate in infants, children, and adolescents. Pediatr Clin North Am 1987;34:571-590.

8 Lowrie E, Zhy X, Lew N: Primary associates of mortality among dialysis patients: trends and reassessement of Kt/V and URR as outcome-based measures of dialysis dose. Am J Kidney Dis 1998;32(suppl 4):S16-S32. $\checkmark 9$ NFK DOQI: Clinical practice guidelines for hemodialysis adequacy and peritoneal dialysis adequacy. Am J Kidney Dis 1997;30:S67S108.

10 Hoffman RS, Smilkstein MJ, Howland MA, Goldfrank LR: Osmolal gap revisited: normal values and limitations. Clin Toxicol 1993;31:81-93.

11 McQuillen KK, Anderson AC: Osmolal gaps in the pediatric population. Acad Emerg Med 1999;6:27-30.

12 Movilli E, Cancarini GC, Cassamali S, Camerini C, Brunori G, Maffei C, Maiorca R: Inter-dialytic variations in blood volume and total body water in uraemic patients treated by dialysis. Nephrol Dial Transplant 2004; 19:185-189. 